\title{
MOSCASUL PROGRAMME: FIRST STEPS OF A PILOT PROJECT TO SUPPRESS THE SOUTH AMERICAN FRUIT FLY IN SOUTHERN BRAZIL
}

\author{
A. KOVALESKI ${ }^{1}$ AND T. MASTRANGELO ${ }^{2}$ \\ ${ }^{1}$ EMBRAPA Uva e Vinho, Estação Experimental de Vacaria, BR 285-Km 115, \\ 95200-000, Vacaria, Rio Grande do Sul, Brazil \\ ${ }^{2}$ Center for Nuclear Energy in Agriculture / Universidade de São Paulo, \\ Av. Centenario 303, 13400-970, Piracicaba, São Paulo, SP, Brazil; \\ piaui@cena.usp.br
}

\begin{abstract}
SUMMARY
In Brazil, $99 \%$ of the apple growing areas are concentrated in the southern region, with an annual harvest of more than 1.2 million tons of fruits and a supply chain amounting to USD 1900 million. Despite the occurrence of several species of tephritid fruit flies in the region, the South American fruit fly, Anastrepha fraterculus (Wiedemann) (Tephritidae) represents $98.5 \%$ of the flies captured in commercial apple orchards. The gross value of yield losses and the cost of associated chemical control of this pest were estimated at close to USD 8 million per year. Moreover, the infestation rate by A. fraterculus has increased during the past four years, as the most commonly used insecticides have been banned. Brazilian researchers, along with state institutes and the Brazilian Association of Apple Producers (ABPM) have been promoting environment-friendly alternatives to insecticide application, such as sterile insects and parasitoids, to suppress the pest, and created the Moscasul Biological Control and Integrated Fruit Fly Management Center. After receiving the support of the Ministry of Agriculture at the end of 2014, almost USD 600000 have been invested in constructing a rearing facility for A. fraterculus at the Agricultural Experiment Station of EMBRAPA (Brazilian Agricultural Research Corporation), Vacaria, Rio Grande do Sul, Brazil. The first containerized laboratory modules were installed in May 2016. During the pre-operational phase of the project, pilot trials were planned in apple orchards at Vacaria. As the Center for Nuclear Energy in Agriculture (CENA) has a $250 \mathrm{~m}^{2}$ facility to produce fruit flies, including radiation sources, the sterile flies for the pilot trials will be initially provided by CENA. Both sterile flies and Diachasmimorpha longicaudata (Ashmead) parasitoids will be released in the surrounding non-commercial vegetation located within a 50$100 \mathrm{~m}$ buffer zone in the periphery of the target orchards, as these areas are the native breeding sites and repositories of the wild flies. Based on the wild population densities of the in the target orchards (114 ha) and the surrounding forested areas $(111 \mathrm{ha})$, about 150000 sterile flies per week will be required for the first pilot phase. After the fine-tuning of all rearing and sterilisation procedures in the beginning of 2017, CENA will ship more than 200000 irradiated pupae weekly by air to Vacaria for 6 months, starting in September when the level of the wild fly population is lower. The results may influence the direction of future control tests and benefit the area-wide management of $A$. fraterculus involving hundreds of apple producers in the region and other temperate fruit growing farmers from southern Brazil.
\end{abstract} Development and Field Application, pp. 215-230. CRC Press, Boca Raton, Florida, USA.

(C) 2021 IAEA 
Key Words: Anastrepha fraterculus, Diachasmimorpha longicaudata, parasitoids, SIT, sterile insects, areawide, apple orchards, wild hosts, Rio Grande do Sul, Santa Catarina, Paraná

\section{INTRODUCTION}

Refuting USA technical reports from the 1960s claiming that producing apples on a commercial scale would be impossible in Brazil, the apple industry has become one of the most recent success stories of fruit producers in the country (Klanovicz 2010). The joint efforts of industry, research institutions and extension services has resulted in an increase in apple yield from 2-4 to 28-30 tons per ha (Klanovicz 2010). In 1986, the First Santa Catarina Apple Festival was celebrated at Fraiburgo, where the Brazilian Association of Apple Producers (Associação Brasileira dos Produtores de Maça - ABPM) launched the campaign "The Brazilian Apple: the sin that worked out right". By 1989, commercial apple production had become firmly established in Brazil (Brazilian Apple Yearbook 2017).

Recently, in only 30 years, Brazil almost reached self-sufficiency in apple production, with a total planted area of 34399 ha, a yield of 38.9 tons/ha and a total of 1247088 tons produced in 2016/2017; the supply chain of the sector amounts to USD 1900 million per year (Brazilian Apple Yearbook 2017). More than 4300 growers are distributed throughout the three southern states of Brazil (Rio Grande do Sul, Santa Catarina and Paraná), where 99\% of Brazil's apple production is located (GAIN Report 2016).

The municipalities of São Joaquim (Santa Catarina state) and Vacaria (Rio Grande do Sul state) have taken turns leading the production volume (ca. 400000 tons in each one, depending of the year) (Brazilian Apple Yearbook 2017). These localities present the most favourable weather conditions, with colder winter temperatures (i.e. more than 900 hours below $7.2^{\circ} \mathrm{C}$ ), mean annual temperature of $15.2^{\circ} \mathrm{C}$, altitudes higher than $800 \mathrm{~m}$, as well as mild summer and autumn days, but with cold nights $\left(10-15^{\circ} \mathrm{C}\right)$, ideal for the physiological processes of temperate fruit trees (Petri et al. 2011).

Despite all the technological advances that allowed the successful establishment of the apple production in the highlands of the states of southern Brazil, the orchards are constantly under threat of important pests like the European red spider mite (Panonychus ulmi Koch), woolly apple aphids (Eriosoma lanigerum Hausmann), Brazilian apple leafroller (Bonagota salubricola Meyrick), oriental fruit moth (Grapholita molesta Busk) and the South American fruit fly (Anastrepha fraterculus Wiedemann).

In October 1991, the codling moth, Cydia pomonella L., was detected in urban areas of four municipalities, but never invaded the commercial farms. Brazil was declared free of this pest in May 2014 after a successful eradication programme that was mainly based on host-tree removal in household backyards of urban and suburban areas (Kovaleski and Mumford 2007).

In 2015, the South American fruit fly became the target of another integrated pest management (IPM) programme. 


\section{IMPORTANCE OF THE SOUTH AMERICAN FRUIT FLY IN SOUTHERN BRAZIL}

The South American fruit fly is a complex of cryptic species that comprises at least eight different morphotypes under the same species designation (Hernández-Ortiz et al. 2012). This complex is distributed from Texas to Argentina and can attack more than 80 species of host fruit trees (Steck 1998; Norrbom 2004). The flies develop within the range of $15-30^{\circ} \mathrm{C}$, and the main biological characteristics at $25^{\circ} \mathrm{C}$ are: preoviposition period of 7-14 days; oviposition until 46-62 days (fecundity can reach 40 eggs/female/day, with an average of 25.2 eggs/female/day, and one female can lay up to 979 eggs during her lifetime); embryogenesis lasts 1-3 days; larval development of 10-14 days and a pupal period of 11-21 days (Machado et al. 1995; Salles 1993, 2000; Vera et al. 2007; Cladera et al. 2014).

The damage caused by $A$. fraterculus on apples occurs soon after the beginning of fruit development (ca. $2 \mathrm{~cm}$ diameter) and is caused by the piercing of the fruit skin by the female ovipositor, causing lesions in the fruit that result in fruit deformations (Magnabosco 1994; Sugayama et al. 1997). In case fully developed fruits get infested, the external symptoms usually do not appear, but the pulp may be destroyed by larvae (Kovaleski et al. 2000).

The pomiculture in southern Brazil has suffered heavy losses due to the attacks of $A$. fraterculus over several years, and the annual yield losses and associated annual costs of chemical control of this pest alone have amounted to more than USD 7.9 million (Salles 1998; Nora and Hickel 2002; Kovaleski and Ribeiro 2003).

Despite the presence of the Mediterranean fruit fly Ceratitis capitata (Wiedemann), Rhagoletis spp., and more than 10 other fruit fly species of the Anastrepha genus in southern Brazil (Kovaleski et al. 2000), A. fraterculus represents $98.5 \%$ of the flies captured in commercial apple orchards (Canal Daza et al. 1994; Nora et al. 2000; Santos et al. 2017).

Pre-harvest management of fruit flies has been implemented almost exclusively with chemical methods, and the control effort has been guided by population monitoring with McPhail traps with a solution of $25 \%$ grape juice or hydrolysed proteins (McPhail 1937; FAO/IAEA 2018) (Fig. 1).

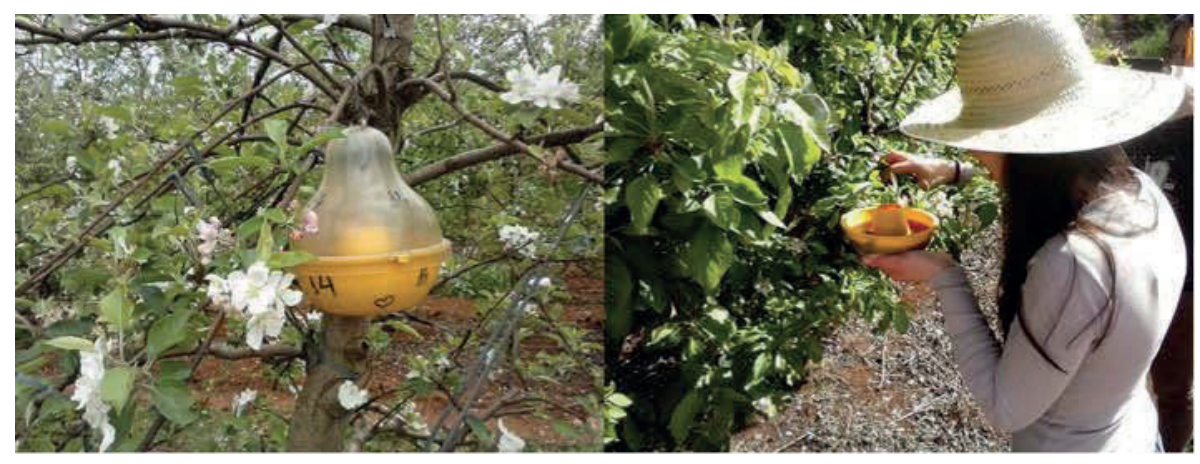

Figure 1. Weekly field monitoring of Anastrepha fraterculus populations in commercial apple orchards with McPhail traps baited with fruit juice or hydrolysed proteins. 
The number of traps deployed depends on the size of the orchards, i.e. 4 traps/ha for areas up to 2 ha, and 2 traps/ha for areas between 2 and 5 ha (Kovaleski et al. 2000). Growers mostly have used a solution of $25 \%$ grape juice as the common attractant with the traps, but there are concerns with respect to their efficiency for fruit fly monitoring in apple orchards (Bortoli et al. 2016). Recent studies have demonstrated that protein-based lures of plant or animal origin (e.g. BioAnastrepha ${ }^{\mathrm{TM}}$ and Ceratrap ${ }^{\mathrm{TM}}$, respectively) are better attractants for $A$. fraterculus (Scoz et al. 2006; Rosa et al. 2017).

As the A. fraterculus populations usually invade apple orchards from the surrounding areas, where they develop on non-commercial preferred hosts (Kovaleski et al. 1996; Sugayama et al. 1997; Santos et al. 2017), growers have traditionally applied weekly toxic bait sprays at the periphery of the apple orchards. The use of these baits (composed of water + insecticide + attractant such as hydrolysed proteins or $5-7 \%$ sugarcane molasses) is intensified in the first months of fruit growth, when the introduction of ovipositor may lead to external fruit deformations (Kovaleski et al. 2000).

When the number of adult flies captured inside the orchard exceeds a threshold level of 0.5 flies per trap per day (FTD) (a threshold level adopted by Brazilian growers since the 1980s), insecticides with systemic action and long residual effects are applied as cover-sprays, usually requiring 8 to 10 applications per season at a cost of about USD 240/ha/year.

Due to their low cost and residual properties (Harter et al. 2015), organophosphate insecticides have been heavily used by Brazilian growers for more than 20 years (Puzzi and Orlando 1957; Salles and Kovaleski 1990; Kovaleski and Ribeiro 2003). Many organophosphate insecticides, however, are being gradually banned or the maximum tolerable residue levels have been drastically reduced for exported fruits and derivatives like juice, concentrates and purees (Rawn et al. 2006; Eddleston et al. 2012). For example, fenthion was the most commercialized insecticide to control $A$. fraterculus in Brazilian apple orchards until 1997, when the growers stopped using it due to the risk of rejection of the fruits on international markets (Kovaleski et al. 2000). In addition, there is the risk of insecticide resistance developing in $A$. fraterculus as reported for C. capitata (Couso-Ferrer et al. 2011).

In order to meet the requirements of international markets for low residues on fruit, growers are increasingly being pushed to avoid insecticide applications against A. fraterculus during longer periods before harvest. Consequently, many apple orchards are being left unprotected from this pest during periods when the fruits are most susceptible.

In the absence of chemical control, the yields of apple orchards can be reduced with up to $30 \%$ due to $A$. fraterculus damage (Kovaleski et al. 2000). The shrinking choice of insecticides available to control A. fraterculus in Brazil, coupled with public demand for sustainable alternatives, have created a significant opportunity for promoting the area-wide augmentative biological control using sterile insects and parasitoids. 


\section{POPULATION DYNAMICS OF THE SOUTH AMERICAN FRUIT FLY IN APPLE ORCHARDS OF SOUTHERN BRAZIL}

Tephritid pest population dynamics are largely affected by climatic features and availability of hosts (Aluja et al. 2012). This was confirmed by the general dynamics of the A. fraterculus populations of the highlands of the midwestern plateau of Santa Catarina and the mountainous region of Rio Grande do Sul, where dynamics of this fly have remained relatively constant for the last 20 years (Salles 1995; Garcia et al. 2003; Calore et al. 2013; Santos et al. 2015, 2017).

Trap captures over a period of 10 years showed that $A$. fraterculus population densities were higher between November and February (spring-summer), but between May and September (autumn-winter) they practically disappear from the commercial apple orchards when mean daily temperatures drop below $15^{\circ} \mathrm{C}$ and host availability is very low (Fig. 2) (Salles and Kovaleski 1990). This pattern of population fluctuation has remained unchanged in most apple orchards to date (Santos et al. 2017).

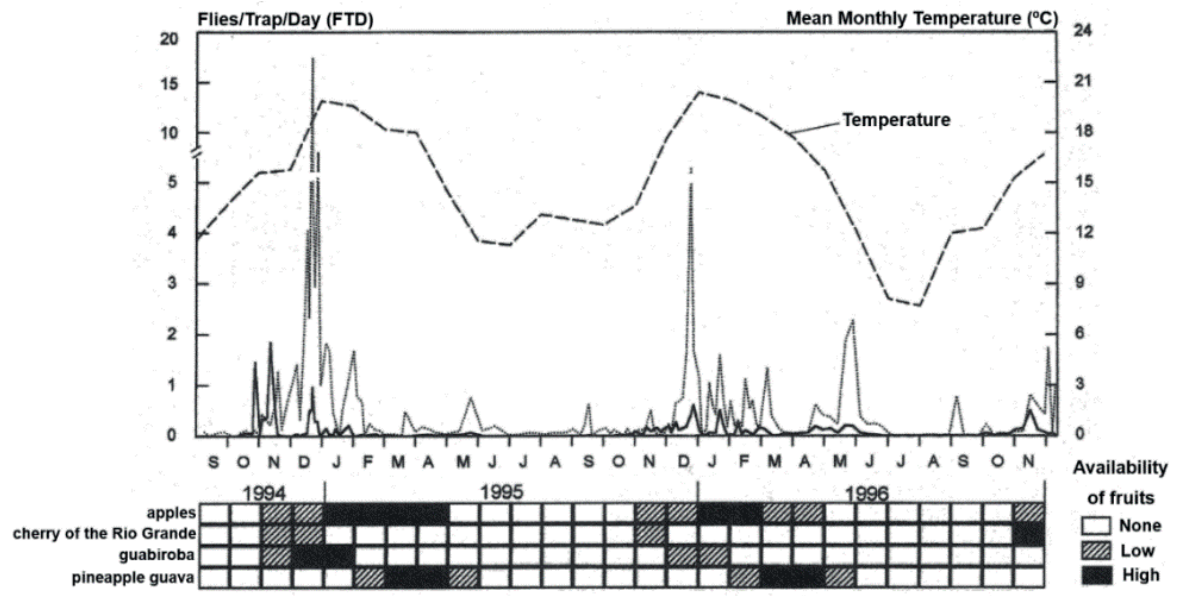

Figure 2. Mean monthly temperatures and population fluctuation of Anastrepha fraterculus (FTD) from commercial apple orchards (represented by a dark solid line) and from adjacent native forest (by a lighter broken line), together with the availability of apples and wild hosts at Vacaria, Rio Grande do Sul from September 1994 to November 1996 (from Kovaleski et al. 2000).

The presence of natural hosts from the family Myrtaceae (Malavasi et al. 1980) in the forested areas, bordering the apple orchards, provide an opportunity for $A$. fraterculus populations to be maintained throughout the year in the region. The natural hosts are mainly the cherry of the Rio Grande (Eugenia involucrata DC), guabiroba (Campomanesia xanthocarpa Berg) and pineapple guava (Feijoa sellowiana Berg) (Fig. 2), which bear fruits in November, December-January, and February-May, respectively (Kovaleski et al. 2000). 
In the beginning of November, the cherries of the Rio Grande can be infested by A. fraterculus females who are residuals from the previous autumn season. When the adults that emerged from the infested cherries become sexually mature, they infest the guabirobas, but available mature apples can also be attacked. After January, pineapple guavas are preferably infested. As the temperatures start to drop in April, the larval development in these guavas can be prolonged until 80 days, and the pupal period can last up to 120 days (Kovaleski 1997; Kovaleski et al. 2000). The flies that emerge in August and beyond May survive until the appearance of new cherries, guabirobas and apples in November (adult overwintering). Thus, autumns with high availability of pineapple guavas and mild winters can be followed by high $A$. fraterculus populations in the spring. The late infestation of apples during MarchApril may also produce a certain amount of pupae, whose adults can emerge at the end of winter (or overwintering as immatures) (Kovaleski et al. 2000). Therefore, the 4-5 months (June - October), when mean temperatures are below $15^{\circ} \mathrm{C}$ and no host fruits are available, cause a natural decline in A. fraterculus populations each year, creating a perfect window of opportunities for the initiation of the release of parasitoids and sterile flies in the forested areas surrounding apple orchards.

The area-wide management of $A$. fraterculus in the commercial apple orchards in southern Brazil is facilitated by the absence of resident populations in the apple orchards, as the natural breeding sites of this pest are the native forests (Kovaleski et al. 1996, 1999; Santos et al. 2017). In the sierra region, where apple orchards and forested areas intermingle, traps located closer to the forested areas generally catch much more flies (e.g. values can even reach 20 FTD) than those deployed inside the orchards (Fig. 3).

Almost $80 \%$ of the damage to fruits occurs in the periphery of the first lines of the apple orchards, because of the prevalence of the foraging behaviour of $A$. fraterculus for oviposition sites and food resources rather than migratory movements (Sugayama 1995; Kovaleski et al. 1996, 1999).

Sugayama et al. (1997) described the diel pattern of $A$. fraterculus in Brazilian apple orchards. When an apple orchard is located closely to forests, most of the flies do not remain in the orchard during the night. The females mostly oviposit their eggs between 16 and $17 \mathrm{~h}$ and at nightfall they return to the forested areas. The fact that apple trees in Brazilian orchards do not form dense canopies that could serve as shelter can contribute to this behaviour. Furthermore, apples can be considered alternative hosts for A. fraterculus (Salles 1995) as most varieties behave as poor hosts. Immature apples are unsuitable hosts, with less than $1 \%$ of survival to pupal stage, and the reproductive rates of $A$. fraterculus in mature apples is usually low (e.g. under field conditions, infestation levels reach $600-800$ pupae $/ \mathrm{kg}$ of apple) (Sugayama 1995; Sugayama et al. 1998; Sugayama and Malavasi 2000).

A decade-long study (Kovaleski et al. 2000) that included fly monitoring, releaserecapture trials and host surveys has demonstrated that $A$. fraterculus populations are primarily present in the forested areas that contain native hosts surrounding the apple orchards (Fig. 3). Consequently, these areas should be the primary targets for suppression and the release of sterile flies and parasitoids starting in September. Maintaining sufficient overflooding ratios throughout the final winter months and spring-summer should theoretically suppress the wild populations. 


\section{THE STERILE INSECT TECHNIQUE AGAINST THE SOUTH AMERICAN FRUIT FLY}

The Sterile Insect Technique (SIT) is an effective and environment-friendly control technology that relies on inundative releases of mass-reared insects, sterilized by ionizing radiation (Dyck et al. 2021). This technique has been applied as a component of many area-wide integrated pest management (AW-IPM) programmes against fruit flies, moths, screwworms and tsetse flies (Vreysen et al. 2007).

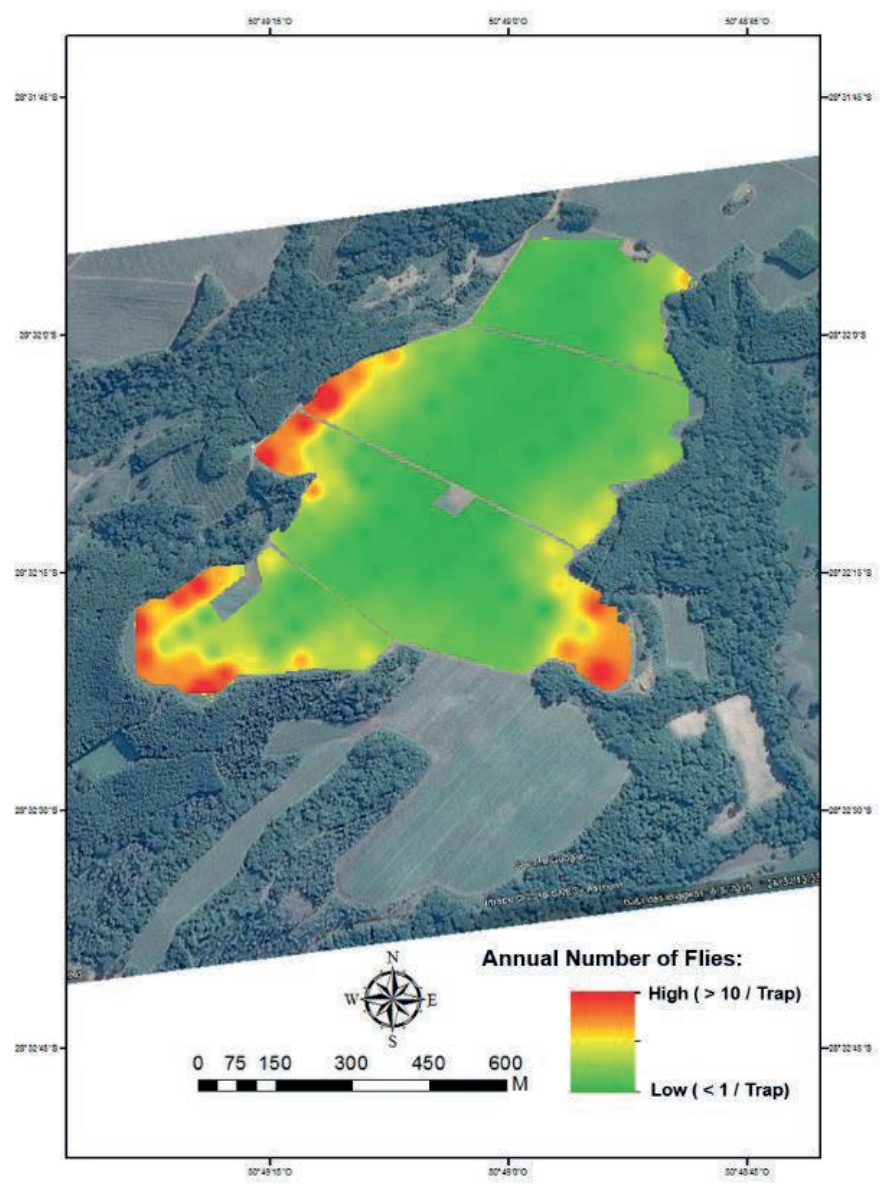

Figure 3. Annual trap catches of wild Anastrepha fraterculus in McPhail traps baited with grape juice in a commercial apple orchard largely surrounded by forest in Vacaria, Rio Grande do Sul, during the 2016-2017 harvest.

For example, almost 300 million sterile flies are produced per week at the Moscafrut facility for the control of several Anastrepha species of economic importance in southern Mexico (Orozco-Davila et al. 2017). In British Columbia, Canada, the wild populations of $C$. pomonella are being kept at minimum levels since 
1997 through the release of sterile moths from the Okanagan-Kootenay Sterile Insect Release (OKSIR) Programme, with populations reduced by $94 \%$ and damage reduced to less than $0.2 \%$ of fruits in more than $90 \%$ of the orchards in the programme area (Judd and Thompson 2012; Simmons et al. 2021; Nelson et al., this volume).

Despite all the knowledge gathered on the biology and genetics of A. fraterculus (Cladera et al. 2014), AW-IPM programmes integrating the SIT against this pest are still not being implemented. The SIT has several technical components and major requirements that need to be met: (1) availability of accurate baseline data on the target wild population (e.g. population density in space and time, dispersal patterns etc.); (2) methods available to mass-rear the insect at reasonable cost; (3) irradiation procedures for proper sterilisation of large batches of the mass-produced insect; (4) a reliable quality control management system of the sterile insects that is applied routinely; (5) transport, fly emergence, handling and release technologies available; (6) adequate sterile to wild male overflooding ratios in the field in order to guarantee a significant induction of sterility in the wild population (Dyck et al. 2021). Most of these issues have been addressed by studies conducted with $A$. fraterculus, especially by researchers from Argentina and Brazil (Ortiz 1999).

Morphological and genetic studies have revealed that $A$. fraterculus is actually a complex of cryptic species (Morgante et al. 1980; Steck 1991), and as a consequence, each morphotype should be treated separately for the successful implementation of the SIT (Whitten and Mahon 2021). At least eight morphotypes have been recognized so far based on integrative taxonomy and their geographic distribution in Latin America has been defined (Hernández-Ortiz et al. 2012, 2015; Devescovi et al. 2014; Hendrichs et al. 2015; Prezotto et al. 2017). The results obtained by Dias et al. (2016) showed the existence of full mating compatibility among $A$. fraterculus populations from southern Brazil (populations from Vacaria, Pelotas, Bento Gonçalves and São Joaquim). Thus, southern Brazilian populations and Argentinean morphotypes are likely to belong to the same species within the A. fraterculus complex (Rull et al. 2012, 2013).

Significant progress has been made with the domestication and artificial rearing of A. fraterculus since the FAO/IAEA Workshop held in Viña del Mar, Chile, in November 1996 (Ortiz 1999), and large colonies have been successfully established in Argentina and Brazil (Salles 1992, 1999; Jaldo et al. 2001; Walder et al. 2006; Vera et al. 2007; Oviedo et al. 2011; Nunes et al. 2013). Walder et al. (2014) developed an artificial rearing system that allows rapid colony built-up and production of enough sterile insects for use in pilot-programmes. The available rearing system can still be optimized to increase insect yields. For example, the rearing costs at the Center for Nuclear Energy in Agriculture from the University of São Paulo (CENA/USP) were reduced by half in 2016 when agar for the larval diet of Salles (1992) was replaced with carrageenan. Ninety litres of pupae (ca. 3 million pupae) of a strain from Vacaria were produced by the $F_{3}$ to the $F_{12}$ generation with mean values of $77.4 \%, 77.0 \%$ and 0.49 for egg hatch, adult emergence and sex ratio $(q / \hat{\sigma}+q)$, respectively (Mastrangelo, unpublished data). 
Radiation experiments with gamma and X-rays have shown that treating pupae of A. fraterculus with a dose of 40-60 Gy can induce 99\% sterility in adult male flies (Bartolucci et al. 2006; Allinghi et al. 2007; Mastrangelo et al. 2010). Although the recommended sterilisation dose for treating pupae $48 \mathrm{~h}$ before emergence has been 70 Gy in Argentina (Cladera et al. 2014; Alba et al. 2016), radiation studies with both gamma and X-rays and field cage tests carried out at CENA/USP with the Vacaria strain in 2016 demonstrated that treating pupae $72 \mathrm{~h}$ before emergence with $40 \mathrm{~Gy}$ is sufficient to produce $99 \%$ sterile flies (that are competitive against wild flies). This dose is sufficient as doses higher than 15 Gy induce complete atrophy of the females' ovaries, and a sterile:wild male overflooding ratio of $45: 1$ induced more than $95 \%$ sterility in wild populations (Mastrangelo et al. 2018).

The sterile flies can be released by static ground-based devices (such as cardboard, plastic or PVC boxes), mobile ground-based systems (such as bags or cardboard containers being released from a mechanical device) (Dominiak et al. 2010; Bjeliš et al. 2013), or as chilled adult flies delivered from small aircrafts or even drones (Tan and Tan 2011; Mubarqui et al. 2014; FAO/IAEA 2017).

Despite all the advances made, some issues must be addressed yet, like automation of rearing processes, strain management and sex separation. Progress has been made to study the cuticular hydrocarbons and the chemical composition of the volatiles emitted by A. fraterculus males (Vanickova et al. 2012; Milet-Pinheiro et al. 2015), but no specific lure is so far commercially available that would increase the accuracy of field-monitoring. Overall, however, nearly all technical problems have been solved by scientists, and the implementation of the SIT against $A$. fraterculus can already be performed at pilot scales.

Most of the AW-IPM campaigns that include the SIT are composed of three phases of implementation: a preparatory pre-operational phase, a population reduction phase applying suppression measures and, then, the sterile insect release phase (Hendrichs et al. 2021). The pre-operational phase includes obtaining the commitment of all stakeholders, the development of funding mechanisms, of physical infrastructure (the establishment of mass-rearing, sterilisation, packing, fly emergence and release facilities) and securing appropriate management and human resources (i.e. strong leadership, dedicated full-time staff, development of institutional capacity, flexible and independent management structure), collection of baseline data on the distribution and population dynamics of the target species, public awareness, pilot trials in the field, continuity of the implementation of the critical components of the project, and independent reviews of it. Although Cladera et al. (2014) stated that most of these human and managerial components were still missing in Argentina, the case in southern Brazil is different. The Brazilian apple industry is strongly organized and competent to support an endeavour against another pest, as demonstrated by the successful eradication of $C$. pomonella achieved in 2014 after a 17-year campaign (Kovaleski and Mumford 2007; Capra 2014).

In north-eastern Brazil, some progress has also been made in the past few years with the management of fruit flies and mosquitoes after the establishment of Moscamed Brasil in the San Francisco River Valley. This programme has focused on the suppression of populations of $C$. capitata in the valley with the integration of sterile males with other suppression methods (Malavasi et al. 2007). More than 20 
million sterile males $C$. capitata were produced for a pilot project in 2006-2007, that successfully suppressed wild populations in more than 2000 ha of mostly mango orchards (Moscamed Brasil 2007). However, most C. capitata populations from the San Francisco River Valley are still very high $($ FTD $>2)$ due to the presence of alternative hosts almost all year round and an excessive number of neglected orchards (França 2016). In southern states, on the other hand, temperate fruit growers can count on a unique climate advantage (natural suppression during the winter) that makes the management of fruit fly populations less costly.

\section{HISTORY OF THE MOSCASUL PILOT PROJECT}

The Moscasul Biological Control and Integrated Fruit Fly Management Center project, including a mass-rearing facility for A. fraterculus and its parasitoids, to be established by EMBRAPA Grape \& Wine and the ABPM, was first presented to the Federal Government of Brazil on September $18^{\text {th }} 2013$, when it obtained the support of the Ministry of Science, Technology and Innovation. In December 2014, the Ministry of Agriculture, Livestock and Food Supply (MAPA) signed a cooperative agreement that included an investment of ca. USD 630000 for the establishment of the Moscasul Center, and that was followed by parliamentary amendments from two senators and one congressman that increased that budget by USD 329000 . The total amount of resources obtained from authorities through these efforts by EMBRAPA and ABPM amounted to almost USD 959000 for the initial phases of the project.

After this initial support, almost USD 600000 were invested in constructing the mass-rearing facility at the Agricultural Experiment Station of EMBRAPA Grape \& Wine at Vacaria, and the first containerized rearing modules were installed in May 2016 (Fig. 4). Twenty-one containers (fifteen larger ones: 12.9 m length x $2.9 \mathrm{~m}$ height $\times 2.4$ width, and six smaller ones: $5.9 \mathrm{~m} \mathrm{x} 2.9 \mathrm{~m} \times 2.4 \mathrm{~m}$ ) were installed in front of the agricultural station.

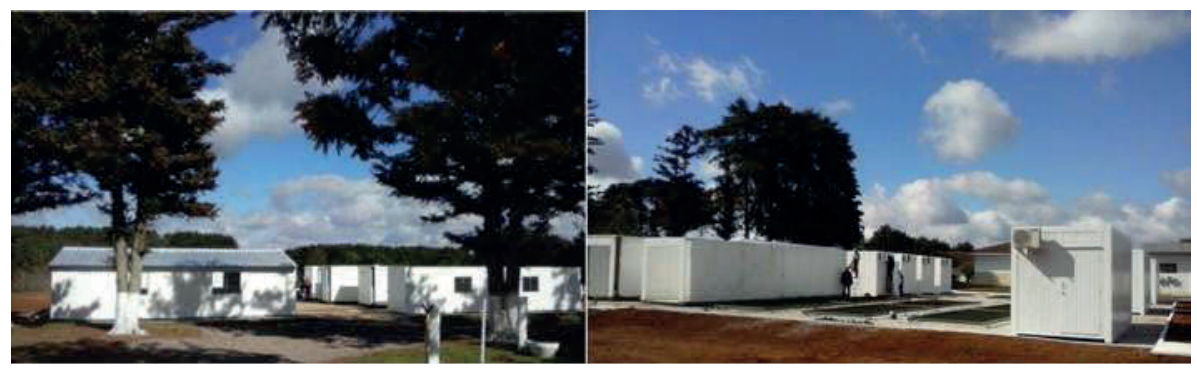

Figure 4. Containerized rearing modules installed for the establishment of the Moscasul Biological Control and Integrated Fruit Fly Management Center at Vacaria, Rio Grande do Sul, Brazil.

Each stage of rearing (i.e. adult colonies, larval rearing, pupal maturation and holding) will take place in separate containers. The selection of a modular system has several advantages: (1) less costly than building an entire single-unit brick facility, 
(2) more species can be reared separately, (3) less susceptible to perturbations of daily operations (Tween 1987), and (4) insect production can be increased depending on the demand and availability of funds.

After the political and economic turmoil in Brazil in 2015, the new Minister of Agriculture visited Vacaria on August $9^{\text {th }}$ 2016, when partnership protocols were signed with representatives of research institutes (Universidade Federal do Rio Grande do Sul and CENA/USP) and growers' associations (ABPM and the state farmer's associations AGAPOMI - Associação Gaúcha dos Produtores de Maçã, SINDOCOPEL - Sindicato das Indústrias de Doces e Conservas Alimentícias de Pelotas, and APPRP - Associação dos Produtores de Pêssego da Região de Pelotas), and an additional USD 158000 were raised from federal funds. In August 2017, EMBRAPA approved an internal project of USD 185000 to support and implement A. fraterculus monitoring and SIT activities.

A gamma or X-ray irradiator still needs to be acquired for the Moscasul Center for the sterilisation of the mass-reared flies. In the meantime, to avoid this constraint and more delays in field tests of the pre-operational phase, the CENA/USP at Piracicaba, São Paulo state, accepted to sterilize the mass-reared flies during the first years of pilot projects. Since the 1970s, research on fruit flies and the SIT has been carried out at this institute, also with the support of the Joint FAO/IAEA Division, and a pilot facility $\left(250 \mathrm{~m}^{2}\right)$ is present since 1998 dedicated to the production of sterile insects of several species (e.g. up to 2 million sterile $C$. capitata can be reared per week) and to training (Walder 2002). This centre is equipped with two gamma irradiators, i.e. a GammaCell-220 ${ }^{\mathrm{TM}}$ and a panoramic Gammabeam-650 $0^{\mathrm{TM}}$ (MDS Nordion International Inc., Canada), and an X-ray irradiator RS 2400V (RadSource Technologies Inc., Buford, Georgia, USA).

A pilot trial has been planned in three large apple orchards in Vacaria to demonstrate to growers the feasibility of using the SIT against $A$. fraterculus. Sterile flies will be released between the months of September and March only in surrounding zones of forests, covering a 50-100 m periphery of the target orchards, since these areas serve as reservoir of wild flies. Based on the monitoring data from 15 consecutive years of the selected orchards, approximately 150000 sterile flies per week would be required for the first pilot release phase. The $A$. fraterculus colonies of the Vacaria strain have been well established at both the EMBRAPA and CENA laboratories. After the fine-tuning of all rearing and sterilisation procedures during the first half of 2017, CENA is planning to ship more than 200000 irradiated pupae weekly by air to Vacaria for 6 months, starting in September when the level of the wild fly population is extremely low in the three pilot areas following the winter (average FTD $<0.5$ ).

Most of the studies on marking and shipment procedures have been completed and the teams have received training in terms of surveillance, distribution of the sterile flies and identification of the caught insects. Depending on the level of production of Diachasmimorpha longicaudata (Ashmead) at EMBRAPA and CENA/USP at the time of the trials, this parasitoid is also intended to be released in some of the areas. The feasibility of shipping irradiated $A$. fraterculus eggs for the mass-rearing of $D$. longicaudata and Doryctobracon areolatus (Szépligeti) at Vacaria is also being assessed (Nunes et al. 2011; Costa et al. 2016). 
Arrangements to establish a pilot trial releasing sterile flies and parasitoids to suppress $A$. fraterculus in peach orchards from the region of Pelotas are also being made. The results of these pilot trails will have the potential to influence the direction of future control tests and to lead towards the sustainable management of $A$. fraterculus by hundreds of apple farmers and other temperate fruit-growing farmers from the southern states of Brazil.

\section{REFERENCES}

Alba, M. G., D. Segura, M. M. Terrada, and S. Lopez. 2016. Estudio comparativo sobre el efecto de la radiación X y gamma sobre pupas de Anastrepha fraterculus (Wied). In D. Quiroga (ed.), Libro de Resumenes: $9^{\text {th }}$ Meeting of Tephritid Workers of the Western Hemisphere, 17-21 October 2016, Buenos Aires, Argentina.

Allinghi, A., C. Gramajo, E. Willink, and J. C. Vilardi. 2007. Induction of sterility in Anastrepha fraterculus (Diptera: Tephritidae) by gamma radiation. Florida Entomologist 90: 96-102.

Aluja, M., M. Ordano, L. Guillen, and J. Rull. 2012. Understanding long-term fruit fly (Diptera: Tephritidae) population dynamics: Implications for areawide management. Journal of Economic Entomology 105: 823-836.

Bartolucci, A., M. T. Vera, V. Yusef, and A. Oviedo. 2006. Morphological characterization of the reproductive system of irradiated Anastrepha fraterculus, pp. 45-52. In R. L. Sugayama, R. A. Zucchi, S. M. Ovruski, and J. Sivinski (eds.), Proceedings of the $7^{\text {th }}$ International Symposium on Fruit Flies of Economic Importance, 10-15 September 2006, Salvador, Brazil.

Bortoli, L. C., R. Machota Jr., F. R. M. Garcia, and M. Botton. 2016. Evaluation of food lures for fruit flies (Diptera: Tephritidae) captured in a citrus orchard of the Serra Gaucha. Florida Entomologist 99: 381-384.

Bjeliš, M., D. Radunić, and P. Bulić. 2011. Pre- and post-release quality of sterile Ceratitis capitata males released by an improved automated ground release machine. Journal of Applied Entomology 137: 154-162.

Brazilian Apple Yearbook. 2017. Anuário brasileiro da maçã de 2017. Editora Gazeta Santa Cruz, Santa Cruz do Sul, Rio Grande do Sul, Brasil. 56 pp.

Calore, R. A., J. C. Galli, W. C. Pazini, R. T. Duarte, and J. A. Galli. 2013. Fatores climáticos na dinâmica populacional de Anastrepha spp. (Diptera: Tephritidae) e de Scymnus spp. (Coleoptera: Coccinellidae) em um pomar experimental de goiaba (Psidium guajava L.). Revista Brasileira de Fruticultura 35: 67-74.

Canal Daza, N. A., R. A. Zucchi, N. M. Silva, and F. L. Leonel Jr. 1994. Reconocimiento de las especies de parasitóides (Hym., Braconidae) de moscas de las frutas (Dip., Tephritidae) en dos municipios del Estado de Amazonas, Brasil. Boletín del Museo de Entomología de la Universidad del Valle 2: $1-17$.

Capra, G. A. 2014. Brazil is free from codling moth. Embrapa Grape \& Wine, Ministry of Agriculture, Livestock and Food Supply. Brasilia, Brasil.

Costa, M. L. Z., M. G. Pacheco, L. A. Lopes, V. W. Botteon, and T. Mastrangelo. 2016. Irradiation of Anastrepha fraterculus (Diptera: Tephritidae) eggs to inhibit fly emergence in the mass-rearing of Diachasmimorpha longicaudata (Hymenoptera: Braconidae). Journal of Insect Science 16: 98-107.

Couso-Ferrer, F., R. Arouri, B. Beroiz, N. Perera, A. Cervera, V. Navarro-Llopis, P. Castañera, P. Hernández-Crespo, and F. Ortego. 2011. Cross-resistance to insecticides in a malathion-resistant strain of Ceratitis capitata (Diptera: Tephritidae). Journal of Economic Entomology 104: 13491356.

Cladera, J. L., J. C. Vilardi, M. Juri, L. E. Paulin, M. C. Giardini, P. V. Gomez Cendra, D. F. Segura, and S. B. Lanzavecchia. 2014. Genetics and biology of Anastrepha fraterculus: Research supporting the use of the Sterile Insect Technique (SIT) to control this pest in Argentina. BMC Genetics 15 (Suppl. 2): S12.

Devescovi, F., S. Abraham, A. K. P. Roriz, N. Nolazco, R. Castañeda, E. Tadeo, C. Cáceres, D. F. Segura, M. T. Vera, I. Joachim-Bravo, N. Canal, and J. Rull. 2014. Ongoing speciation within the Anastrepha fraterculus cryptic species complex: The case of the Andean morphotype. Entomologia Experimentalis et Applicata 152: 238-247. 
Dias, V. S., J. C. Silva, K. M. Lima, C. S. C. D. Petitinga, V. Hernández-Ortiz, R. A. Laumann, B. J. Paranhos, K. Uramoto, R. A. Zucchi, and I. S. Joachim-Bravo. 2016. An integrative multidisciplinary approach to understanding cryptic divergence in Brazilian species of the Anastrepha fraterculus complex (Diptera: Tephritidae). Biological Journal of the Linnean Society 117: 725-746.

Dominiak, B. C., S. Sundaralingam, L. Jiang, A. J. Jessup, and I. M. Barchia. 2010. Impact of marker dye on adult eclosion and flight ability of mass-produced Queensland fruit fly Bactrocera tryoni (Froggatt) (Diptera: Tephritidae). Australian Journal of Entomology 49: 166-169.

Dyck, V. A., J. Hendrichs, A. S. Robinson (eds.). 2021. Sterile Insect Technique - Principles and practice in Area-Wide Integrated Pest Management. Second Edition. CRC Press, Boca Raton, Florida, USA. $1200 \mathrm{pp}$.

Eddleston, M., S. Adhikari, S. Egodage, H. Ranganath, F. Mohamed, G. Manuweera, S. Azher, S. Jayamanne, E. Juzczak, M. R. Sheriff, A. H. Dawson, and N. A Buckley. 2012. Effects of a provincial ban of two toxic organophosphorus insecticides on pesticide poisoning hospital admissions. Clinical Toxicology 50: 202-209.

(FAO/IAEA) Food and Agriculture Organization of the United Nations/International Atomic Energy Agency. 2017. Guideline for packing, shipping, holding and release of sterile flies in areawide fruit fly control programmes. J. L. Zavala-López and W. R. Enkerlin (eds.). Second Edition, Rome, Italy. 140 pp.

(FAO/IAEA) Food and Agriculture Organization of the United Nations/International Atomic Energy Agency. 2018. Trapping guidelines for area-wide fruit fly programmes. W. R. Enkerlin, and J. Reyes-Flores, J. (eds.). Second edition. Rome, Italy. 65 pp.

França, P. R. P. 2016. Flutuação populacional de moscas-das-frutas (Diptera: Tephritidae) em pomares comerciais de mangueira e viabilidade de implantação de área de baixa prevalência em Petrolina, Pernambuco. Dissertation, Universidade Federal de Viçosa, Minas Gerais, Brasil. 50 pp.

(GAIN) Global Agricultural Information Network Report. 2016. USDA Foreign Agricultural Service. Brazil Annual Fresh Deciduous Fruit Report. GAIN Report Number: BR 1617.

Garcia, F. R. M., J. V. Campos, and E. Corseiul. 2003. Flutuação populacional de Anastrepha fraterculus (Wiedemann, 1830) (Diptera, Tephritidae) na região oeste de Santa Catarina, Brasil. Revista Brasileira de Entomologia 47: 415-420.

Hendrichs, J., T. Vera, M. de Meyer, and A. Clarke. 2015. Resolving cryptic species complexes of major tephritid pests. ZooKeys 540: 5-39.

Hendrichs, J., M. J. B. Vreysen, W. R. Enkerlin, and J. P. Cayol. 2021. Strategic options in using sterile insects for area-wide integrated pest management, pp. 839-882. In V.A. Dyck, J. Hendrichs, and A.S. Robinson (eds.), Sterile Insect Technique - Principles and practice in Area-Wide Integrated Pest Management. Second Edition. CRC Press, Boca Raton, Florida, USA.

Harter, W. R., M. Botton, D. E. Nava, A. D. Grutzmacher, R. S. Gonçalves, R. M. Junior, D. Bernardi, and O. Z. Zanardi. 2015. Toxicities and residual effects of toxic baits containing spinosad or malathion to control the adult Anastrepha fraterculus (Diptera: Tephritidae). Florida Entomologist 98: 202-208.

Hernández-Ortiz, V., A. F. Bartolucci, P. Morales-Valles, D. Frias, and D. Selivon. 2012. Cryptic species of the Anastrepha fraterculus complex (Diptera: Tephritidae): A multivariate approach for the recognition of South American morphotypes. Annals of the Entomological Society of America 105: 305-318.

Hernández-Ortiz, V., N. A. Canal, J. O. T. Salas, F. M. Ruíz-Hurtado, and J. F. Dzul-Cauich. 2015. Taxonomy and phenotypic relationships of the Anastrepha fraterculus complex in the Mesoamerican and Pacific Neotropical dominions (Diptera, Tephritidae). ZooKeys 540: 95-124.

Jaldo, H. E., M. C. Gramajo, and E. Willink. 2001. Mass rearing of Anastrepha fraterculus (Diptera: Tephritidae): A preliminary strategy. Florida Entomologist 84: 716-718.

Judd, G., and D. Thompson. 2012. Taking a flexible approach to mating disruption in British Columbia. In Abstracts from the $86^{\text {th }}$ Orchard Pest Management Conference, January 11-13 2012, Portland, Oregon, USA.

Klanovicz, J. 2010. Toxicity and apple production in southern Brazil. História, Ciências, Saúde Manguinhos, vol. 17, no. 1 (Jan.-Mar 2010), Rio de Janeiro, Brazil. 18 pp.

Kovaleski, A. 1997. Processos adaptativos na colonização da maçã (Malus domestica) por Anastrepha fraterculus (Wied.) (Diptera: Tephritidae) na região de Vacaria, Rio Grande do Sul. Thesis Doutorado em Ciências. Instituto de Biociências, Universidade São Paulo, São Paulo Brasil. 122 pp. 
Kovaleski, A., and L. G. Ribeiro. 2003. Manejo de pragas na produção integrada de maçãs. Circular Técnica, 34. Embrapa Uva e Vinho, Bento Gonçalves, Rio Grande do Sul, Brasil. 7 pp.

Kovaleski, A., and J. Mumford. 2007. Pulling out the evil by the root: The codling moth Cydia pomonella eradication programme in Brazil, pp. 581-590. In M. J. B Vreysen, A. S. Robinson, and J. Hendrichs (eds.), Area-wide control of insect pests: From research to field implementation. Springer, Dordrecht, The Netherlands.

Kovaleski, A., K. Uramoto, R. L. Sugayama, N. A. Canal, and A. Malavasi. 1996. A survey of Anastrepha species present in apple growing area from Rio Grande do Sul, Brazil, pp. 32. In Proceedings $2^{\text {nd }}$ Meeting of the Working Group on Fruit Flies of the Western Hemisphere, Viña del Mar, Chile.

Kovaleski, A., R. L. Sugayama, and A. Malavasi. 1999. Movement of Anastrepha fraterculus from native breeding sites into apple orchards in southern Brazil. Entomologia Experimentalis et Applicata 91: 457-463.

Kovaleski, A., R. L. Sugayama, K. Uramoto and A. Malavasi. 2000. Rio Grande do Sul, pp. 285-290. In A. Malavasi, and R. A. Zucchi (eds.), Moscas-das-frutas de importância econômica no Brasil: Conhecimento básico e aplicado. FAPESP-Holos, Ribeirão Preto, São Paulo, Brasil.

Machado, A. E., L. A. B. Salles, and A. E Loeck. 1995. Exigências térmicas de Anastrepha fraterculus (Wied.) e estimativa do número de gerações em Pelotas, RS. Anais da Sociedade Entomológica do Brasil 24: 573-579.

Magnabosco, A. L. 1994. Influência de fatores físicos e químicos de maçãs, cv. Gala, no ataque e desenvolvimento larval de Anastrepha fraterculus (Wied., 1830) (Diptera: Tephritidae). Dissertation Mestrado em Fitossanidade, Curso de Pós-graduação em Agronomia, Universidade Federal de Pelotas, Rio Grande do Sul, Brasil. 95 pp.

Malavasi, A., J. S. Morgante, and R. A. Zucchi. 1980. Biologia de 'moscas-das-frutas' (Diptera: Tephritidae). I. Lista de hospedeiros e ocorrência. Revista Brasileira de Biologia 40: 9-16.

Malavasi, A., A. Nascimento, B. A. J. Paranhos, M. L. C. Costa, and J. M. M. Walder. 2007. Implementation of a medfly, fruit fly parasitoids and codling moth rearing facility in northeastern Brazil, pp. 527-534. In M. J. B. Vreysen, A. S. Robinson, and J. Hendrichs (eds.), Area-wide control of insect pests: From research to field implementation. Springer, Dordrecht, The Netherlands.

Mastrangelo, T., A. G. Parker, A. Jessup, R. Pereira, D. Orozco-Dávila, A. Islam, T. Dammalage, and J. M. Walder. 2010. A new generation of X ray irradiators for insect sterilisation. Journal of Economic Entomology 103: 85-94.

Mastrangelo, T., A. Kovaleski, V. Botteon, W. Scopel, and M. L. Z. Costa. 2018. Optimization of the sterilizing doses and overflooding ratios for the South American fruit fly. PLoS One 13:e0201026.

Milet-Pinheiro, P., D. M. A. Navarro, N. C. De Aquino, L. L. Ferreira, R. F. Tavares, R. C. C. Da Silva, A. Lima Mendonça, L. Vaníčková, A. L. Mendonça, and R. R. do Nascimento. 2015. Identification of male-borne attractants in Anastrepha fraterculus (Diptera: Tephritidae). Chemoecology 25: 115-122.

Morgante, J. S., A. Malavasi, and G. L. Bush. 1980. Biochemical systematics and evolutionary relationships of neotropical Anastrepha. Annals of Entomological Society of America 73: 622-630.

Moscamed Brasil. 2007. Relatório anual de atividades da biofábrica Moscamed Brasil de 2007.

Mubarqui, R. L., R. C. Perez, R. A. Kladt, J. L. Z. Lopez, A. Parker, M. T. Seck, B. Sall, and J. Bouyer. 2014. The smart aerial release machine, a universal system for applying the Sterile Insect Technique. PLoS One 9(7): e103077.

McPhail, M. 1937. Relation of time of day, temperature, and evaporation to attractiveness of fermenting sugar solution to Mexican fruit fly. Journal of Economic Entomology 30: 793-799.

Nora, I., and E. R. Hickel. 2002. Pragas da macieira, pp. 463-498. In A Cultura da macieira. EpagriItajaí, Florianópolis, Santa Catarina, Brasil.

Nora, I., E. R. Hickel, and H. F. Prado. 2000. Moscas-das-frutas nos estados brasileiros: Santa Catarina, pp. 271-275. In A. Malavasi and R.A. Zucchi (eds.), Moscas-das-frutas de importância econômica no Brasil: Conhecimento básico e aplicado. FAPESP-Holos, Ribeirão Preto, São Paulo, Brasil.

Norrbom, A. L. 2004. Host plant database for Anastrepha and Toxotrypana (Diptera: Tephritidae); Diptera data dissemination disk. North American Dipterist's Society, Washington, DC, USA.

Nunes, A. M., D. E. Nava, F. A. Muller, R. S. Gonçalves, and M. S. Garcia. 2011. Biology and parasitic potential of Doryctobracon areolatus on Anastrepha fraterculus larvae. Pesquisa Agropecuária Brasileira 46: 669-671. 
Nunes A. M., K. Z. Costa, K. M. Faggioni, M. L. Z. Costa, R. S. Gonçalves, J. M. M. Walder, M. S. Garcia, and D. E. Nava. 2013. Dietas artificiais para a criação de larvas e adultos da mosca-dasfrutas sul-americana. Pesquisa Agropecuária Brasileira 48: 1309-1314.

Orozco-Davila, D., L. Quintero, E. Hernández, E. Solis, T. Artiaga, R. Hernández, C. Ortega, and P. Montoya. 2017. Mass rearing and sterile insect releases for the control of Anastrepha spp. pests in Mexico-A review. Entomologia Experimentalis et Applicata 164: 176-187.

Ortiz, G. 1999. Introduction, pp. 1-2. In The South American fruit fly, Anastrepha fraterculus (Wied.): Advances in artificial rearing, taxonomic status and biological studies. Proceedings of FAO/IAEA Anastrepha fraterculus Workshop, 1-2 November 1996, Viña del Mar, Chile. IAEA-TECDOC-1064, IAEA, Vienna, Austria.

Oviedo, A., D. Nestel, N. T. Papadopoulos, M. J. Ruiz, S. C. Prieto, E. Willink, and M. T. Vera. 2011. Management of protein intake in the fruit fly Anastrepha fraterculus. Journal of Insect Physiology 57: $1622-1630$.

Petri, J. L., G. B. Leite, M. Couto, and P. Francescatto. 2011. Advances of the apple crop in Brazil. Revista Brasileira de Fruticultura 33: 48-56.

Puzzi, D., and A. Orlando. 1957. Ensaios de combate às "Mosca-das-frutas" Ceratitis capitata (Wied.) e Anastrepha spp. por meio de pulverizações de iscas envenenadas. O Biológico 23: 21-25.

Prezotto, L. F., A. L. P. Perondini, V. Hernández-Ortiz, C. L. Marino, and D. Selivon. 2017. Wolbachia strains in cryptic species of the Anastrepha fraterculus complex (Diptera, Tephritidae) along the Neotropical region. Systematic and Applied Microbiology 40: 59-67.

Rawn, D. F. K., S. C. Quade, J. Shields, G. Conca, W. F. Sun, G. M. A. Lacroix, M. Smith, A. Fouquet, and A. Belanger. 2006. Organophosphate levels in apple composites and individual apples from a treated Canadian orchard. Journal of Agricultural and Food Chemistry 54: 1943-1948.

Rosa, J. M., C. J. Arioli, J. P. dos Santos, A. C. Menezes-Netto, and M. Botton. 2017. Evaluation of food lures for capture and monitoring of Anastrepha fraterculus (Diptera: Tephritidae) on temperate fruit trees. Journal of Economic Entomology 110: 995-1110.

Rull, J., S. Abraham, A. Kovaleski, D. F. Segura, A. Islam, V. Wornoayporn, T. Dammalage, U. S. Tomas, and M. T. Vera. 2012. Random mating and reproductive compatibility among Argentinean and southern Brazilian populations of Anastrepha fraterculus (Diptera: Tephritidae). Bulletin of Entomological Research 102: 435-443.

Rull, J., S. Abraham, A. Kovaleski, D. F. Segura, M. Mendoza, M. C. Liendo, and M. T. Vera. 2013. Evolution of pre-zygotic and post-zygotic barriers to gene flow among three cryptic species within the Anastrepha fraterculus complex. Entomologia Experimentalis et Applicata 148: 213-222.

Santos, J. P., L. R. Redaelli, J. Sant'Ana, and E. R. Hickel. 2015. Suscetibilidade de genótipos de macieira a Anastrepha fraterculus (Diptera: Tephritidae) em diferentes condições de infestação. Revista Brasileira de Fruticultura 37: 77-83.

Santos, J. P., L. R. Redaelli, J. Sant'Ana, and E. R. Hickel. 2017. Population fluctuation and estimate of generations number of Anastrepha fraterculus (Diptera: Tephritidae) in apple orchard in Caçador, Santa Catarina, Brazil. Arquivos do Instituto Biológico 84: 1-7, e0482015.

Salles, L. A. B. 1992. Metodologia de criação de Anastrepha fraterculus (Wied.) (Diptera: Tephritidae) em dieta artificial em laboratório. Anais da Sociedade Entomológica do Brasil 21: 479-486.

Salles, L. A. B. 1993. Efeito da temperatura constante na oviposição e no ciclo de vida de Anastrepha fraterculus. Anais da Sociedade Entomológica do Brasil 22: 57-62.

Salles, L. A. B. 1995. Bioecologia e controle da mosca-das-frutas sul-americana. Embrapa-CPACT, Pelotas, Rio Grande do Sul, Brasil. 58 pp.

Salles, L. A. B. 1998. Principais pragas e seu controle, pp. 205-242. In M. C. B. R. Raseira (ed.), A cultura do pessegueiro. Brasília: Embrapa-SPI; Embrapa-CPACT, Pelotas, Rio Grande do Sul, Brasil.

Salles, L. A. B. 1999. Rearing of Anastrepha fraterculus (Wiedemann), pp. 95-100. In The South American fruit fly, Anastrepha fraterculus (Wied.): Advances in artificial rearing, taxonomic status and biological studies. Proceedings of FAO/IAEA Anastrepha fraterculus Workshop, 1-2 November 1996, Viña del Mar, Chile. IAEA-TECDOC-1064. IAEA, Vienna, Austria.

Salles, L. A. B. 2000. Biologia e ciclo de vida de Anastrepha fraterculus (Wied.), pp. 81-86. In A. Malavasi and R. A. Zucchi (eds.), Moscas-das-frutas de importância econômica no Brasil: Conhecimento básico e aplicado. Holos Editora, Ribeirão Preto, São Paulo, SP, Brasil.

Salles, L. A. B., and A. Kovaleski. 1990. Inseticidas para controle da mosca-das-frutas. Horti Sul 1(3): 10-11.

Simmons, G. S., K. A. Bloem, S. Bloem, J. E. Carpenter, and D. M. Suckling. 2021. Impact of moth suppression/eradication programmes using the Sterile Insect Technique or inherited sterility, pp. 
1005-1048. In V.A. Dyck, J. Hendrichs, and A.S. Robinson (eds.), Sterile Insect Technique Principles and practice in Area-Wide Integrated Pest Management. Second Edition. CRC Press, Boca Raton, Florida, USA.

Sugayama, R. L. 1995. Comportamento, demografia, e ciclo de vida de Anastrepha fraterculus Wied. (Diptera: Tephritidae) associada a três cultivares de maçã no sul do Brasil. Dissertation Mestrado, Instituto de Biosciências, Universidade de São Paulo, Piracicaba, SP, Brasil. 97 pp.

Sugayama, R. L. 2000. Anastrepha fraterculus (Wiedeman) (Diptera: Tephritidae) na região produtora de maçãs do Rio Grande do Sul: Relação com os inimigos naturais e potencial para o controle biológico. PhD thesis, Instituto de Biociências, Universidade de São Paulo, São Paulo, SP, Brasil.

Sugayama, R. L., and A. Malavasi. 2000. Ecologia comportamental, pp. 99-108. In A. Malavasi and R. A. Zucchi (eds.), Moscas das frutas de importância econômica no Brasil: Conhecimento básico e aplicado. FAPESP-Holos Editora, Ribeirão Preto, São Paulo, SP, Brasil.

Sugayama, R. L., E. S. Branco, A. Malavasi, A. Kovaleski, and I. Nora. 1997. Oviposition behavior and preference of Anastrepha fraterculus in apple and dial pattern of activity in an apple orchard in Brazil. Entomologia Experimentalis et Applicata 83: 239-245.

Sugayama, R. L., A. Kovaleski, P. Liedo, and A. Malavasi. 1998. Colonization of a new fruit crop by Anastrepha fraterculus (Diptera: Tephritidae) in Brazil: A demographic analysis. Environmental Entomology 27: 642-648.

Scoz, P. L., M. Botton, M. S. Garcia, and P. L. Pastori. 2006. Avaliação de atrativos alimentares e armadilhas para o monitoramento de Anastrepha fraterculus (Wiedemann, 1830) (Diptera: Tephritidae) na cultura do pessegueiro (Prunus pérsica). Idesia (Arica) 24: 7-13.

Steck, G. J. 1998. Taxonomic status of Anastrepha fraterculus, pp. 13-20. In The South American fruit fly, Anastrepha fraterculus (Wied.): Advances in artificial rearing, taxonomic status and biological studies. Proceedings of FAO/IAEA Anastrepha fraterculus Workshop, 1-2 November 1996, Viña del Mar, Chile. IAEA-TECDOC 1064. IAEA, Vienna, Austria.

Steck, G. J. 1991. Biochemical systematics and population genetic structure of Anastrepha fraterculus and related species (Diptera: Tephritidae). Annals of Entomological Society of America 84:10-28.

Tan, L. T., and K. H. Tan. 2011. Alternative air vehicles for Sterile Insect Technique aerial release. Journal of Applied Entomology 137: 126-141.

Tween, G. 1987. A modular approach to fruit fly production facilities for the Mediterranean fruit fly Central American program, pp. 283-291. In A.P. Economopoulos (ed.), Proceedings of Second International Symposium on Fruit Flies of Economic Importance, 16-21 September 1986, Crete, Greece. Elsevier Science Publishers, Amsterdam, The Netherlands.

Vanickova, L., A. Svatos, J. Kroiss, M. Kaltenpoth, R. R. Nascimento, M. Hoskovec, R. Bř́zová, and B. Kalinova. 2012. Cuticular hydrocarbons of the South American fruit fly Anastrepha fraterculus: variability with sex and age. Journal of Chemical Ecology 38: 1133-1142.

Vera, M. T., S. Abraham, A. Oviedo, and E. Willink. 2007. Demographic and quality control parameters of Anastrepha fraterculus (Diptera: Tephritidae) maintained under artificial rearing. Florida Entomologist 90: 53-57.

Vreysen, M. J. B., J. Gerardo-Abaya, and J. P. Cayol. 2007. Lessons from Area-Wide Integrated Pest Management (AW-IPM) programmes with an SIT component: An FAO/IAEA perspective, pp. 723 744. In M. J. B. Vreysen, A. S. Robinson, and J. Hendrichs (eds.), Area-wide control of insect pests: From research to field implementation. Springer, Dordrecht, The Netherlands.

Walder, J. M. M. 2002. Produção de moscas-das-frutas e seus inimigos naturais: Associação de moscas estéreis e controle biológico, pp. 181-190. In J. R. P. Parra, P. S. M. Botelho, B. S. Correa-Ferreira, and J. M. S. Bento (eds.), Controle biológico no Brasil: Parasitóides e predadores. Editora Manole, São Paulo, SP, Brasil.

Walder, J. M. M., M. L. Z. Costa, and T. A. Mastrangelo. 2006. Developing mass-rearing system for Anastrepha fraterculus and Anastrepha obliqua for future SIT-AWIPM procedures in Brazil. In $1^{\text {st }}$. Progress Report: FAO/IAEA $2^{\text {nd }}$ Research Coordination Meeting, 5-9 September, Salvador, Bahia, Brazil.

Walder, J. M. M., R. Morelli, K. Z. Costa, K. M. Faggioni, P. A. Sanches, B. A. J. Paranhos, J. M. S. Bento, and M. L. Z Costa. 2014. Large scale artificial rearing of Anastrepha sp.1 aff. fraterculus (Diptera: Tephritidae) in Brazil. Scientia Agricola 71: 281-286.

Whitten, M., and R. Mahon. 2021. Misconceptions and constraints driving opportunities, pp. 45-74. In V. A. Dyck, J. Hendrichs, and A. S. Robinson (eds.), Sterile Insect Technique - Principles and practice in Area-Wide Integrated Pest Management. Second Edition. CRC Press, Boca Raton, Florida, USA. 